\title{
Decentralisation, Rural Livelihoods and Pasture-Land Management in Post-Socialist Mongolia
}

\author{
ROBIN MEARNS
}

\section{INTRODUCTION AND OBJECTIVES}

In 1990 Mongolia embarked on a far-reaching series of political and economic reforms following the demise of the former Soviet bloc, of which it had been a part for some 70 years. In common with post-communist transitions elsewhere, these reforms aimed to bring about a separation of the political, executive and judicial pillars of the state, and to increase the role of markets rather than the state in allocating resources within society. This reform agenda remains far from complete, however, and is far less tidy in practice than the notion of 'transition' implies [see also Nelson et al., 1997]. Contemporary Mongolia is characterised by a mosaic of formal and informal institutions, including the results of new experiments in policy-making seen alongside the remnants of old arrangements and patterns of behaviour.

Any attempt to understand the forms that decentralisation has taken in Mongolia to date, and its consequences for natural resource management, must be seen in and distinguished from this broader context of post-socialist transition. A problem of attribution arises. Post-socialist transition and decentralisation both involve the transfer of powers from state to non-state bodies and efforts to increase the accountability of public institutions. 'Decentralisation' is here understood to refer to formal transfers of power 'to actors and institutions at lower levels within a political-administrative and territorial hierarchy' [Agrawal and Ribot, 1999: 475]. 'Democratic decentralisation', more specifically, is said to occur when 'power and resources are transferred to authorities representative of and downwardly

\footnotetext{
Robin Mearns is Senior Natural Resource Management Specialist at the World Bank, based in Hanoi, Vietnam. This is a revised version of a paper first presented at the World Resources Institute Conference on 'Decentralisation and the Environment', Bellagio, Italy, 18-22 Feb. 2002. This contribution has benefited from the comments and suggestions of Jesse Ribot, Anne Larson, Nancy Peluso and two anonymous referees, and from discussions with other conferees. The interpretations and conclusions expressed in this contribution are entirely those of the author and do not necessarily represent the views of the World Bank, its Executive Directors, or the countries they represent.
}

European Journal of Development Research, Vol.16, No.1, Spring 2004, pp.133-152 ISSN 0957-8811 print DOI: $10.1080 / 09578810410001688770$ C 2004 Taylor \& Francis Ltd. 
accountable to local populations' [Ribot, 2002: 4]. Although they have so far been modest in scope, and stronger in rhetoric than in reality, government efforts to advance a democratic decentralisation agenda in Mongolia may be regarded as a subset of the broader domain of transition reforms - which also include some of the institutional prerequisites for decentralisation of natural resource management to work in practice (that is, a closer specification of property and resource-access rights and credible rule-enforcement mechanisms). The problem of attribution arises because of the difficulty of distinguishing the outcomes of these overlapping sets of policy reforms in terms of their consequences for local livelihoods and natural resource management practices. ${ }^{1}$

This contribution makes no claims to resolve this problem of attribution. It begins by describing what is intended by 'decentralisation' in statements of current government policy, contrasting this with the forms decentralisation takes in practice, and offering a brief synopsis of the current status of decentralisation in Mongolia - benchmarked against a number of other developing countries. We then apply the 'actors, powers and accountability' framework [Agrawal and Ribot, 1999; Ribot, 2002] to show how certain farreaching policy reforms over the past decade, including important elements of democratic decentralisation [Manor, 1999], have contributed to significant changes in local livelihoods and pasture-land management practices. While the stated intentions of many of the reforms in question are to promote social inclusion and environmental justice ${ }^{2}$, their practical outcomes currently have precisely the opposite effects. Finding that these adverse outcomes are in part a reflection of incomplete decentralisation, the contribution concludes with reflections on some of the critical missing elements of a democratic decentralisation agenda that could help to restore social and environmental justice in pasture-land use and management.

This case study is based on field research by the author on pastoral livelihoods in areas representing diverse ecological and market-access conditions throughout rural Mongolia in several periods over the course of the 1990s [Mearns, 1993a, b, 1996, 1997; NSO and World Bank, 2001³], insights gained from the author's ongoing management of the World Bank's support for 'pro-poor' rural development in Mongolia, and published secondary sources.

\section{DECENTRALISATION AS POLICY}

To what extent is decentralisation currently claimed as a tenet of policy by the government of Mongolia, both in general and in relation to natural resource governance and environmental justice in particular? Textual analysis of relevant official documents reveals that 'decentralisation' is intended in several different and potentially far-reaching ways. General statements of 
intent are offered in the government's overall Action Programme, which mirrors the manifesto on which the present government was elected with a landslide victory in June 2000 [GoM, 2000a]. This document sets out an ambitious agenda, including: the promotion of regional and rural development, in part to address the over-concentration of economic opportunity in the capital city and central, more market-accessible regions of the country; ${ }^{4}$ increasing accountability in the public sector; increasing the capacity of local governments to generate revenues over which they have discretionary control; and offering citizens 'greater opportunity to directly monitor the performance of their elected Citizen's [sic] Representative Hural [assemblies] and the executive agencies nominated by the Hural' [GoM, 2000a: 53].

Other relevant declarations of government policy include the recently enacted Public Sector Management and Finance Law (PSMFL), which seeks to increase the accountability and effectiveness of public sector institutions at all levels while also respecting the need for fiscal restraint and sustainability $[G o M, 2002 a]$. The PSMFL calls for a shift from input-based budgeting to output- or performance-based budgeting, aims to put more authority in the hands of local assemblies and clarify the responsibilities of local governments, overhauls the existing system of inter-governmental transfers, and devolves service-delivery functions to local providers - under the oversight of local assemblies [World Bank, 2002].

The government's Good Governance for Human Security Programme refers to 'decentralizing and empowering local self-governance and local administration' [GoM, 2001: 12], and aims to support 'stakeholder consultation, voice, and participation' in the broader policy process, including 'monitoring ... citizen satisfaction and recommendations with regard to services, rights, and government responsiveness to citizen demands' [GoM, 2001: 14]. The government's Economic Growth Support and Poverty Reduction Strategy (EGSPRS) echoes the broad theme of raising public accountability, notably through greater public voice in and scrutiny of the budget process [GoM, 2003b].

Concerning claims for decentralisation as policy with more specific respect to the environment, most official sources [NCSDM, 1999; GoM, 2000b] refer principally to the need to enhance citizen voice and participation in decisionmaking, monitoring and evaluation, usually mediated through civil society institutions. These are not binding policy documents, however, and few concrete, budgeted proposals are made to advance them. In the case of the National Environmental Action Plan, cursory mention is made of the principle of subsidiarity: 'decisions on environmental issues are to be taken at the lowest appropriate level' [GoM, 2000b: 16]. The EGSPRS, however, goes further than most other government documents in outlining a strategy with respect to natural resource governance that involves support for herder groups to 
undertake collective action in grassland and pastoral risk management, and support for effective implementation of the land law. A recently formulated rural development strategy, prepared in part as an input to the EGSPRS, fleshes this out in further detail [CPR, 2002].

\section{DECENTRALISATION IN PRACTICE}

To what extent is this democratic decentralisation agenda being translated into practice? In this section, we consider some of the binding physical, demographic and fiscal constraints before turning to the specific case of pasture-land management.

With a total population of 2.4 million people in an area virtually the size of Western Europe, Mongolia is probably the most sparsely populated country in the world. Excluding the population of the capital city, Ulaanbaatar - in which one-third of the total population lives [NSO, 2001], ${ }^{5}$ there is an average of roughly one square kilometre of land for every person.

There are three levels of sub-national administration below central government: aimags and the capital city have provincial status; next down the hierarchy fall sums (rural districts) and duuregs (urban districts of the capital city); and lowest of all are bags (rural sub-districts) and khoroos (urban subdistricts). Aimags have an average population of around 75,000; sums around 5,000; and bags less than 1,000. There is an elected assembly, or khural, at each of the three tiers of sub-national government. ${ }^{6}$ Each sub-national level also has an executive administration headed by a governor who is nominated by the respective khural and formally appointed by the governor at the next-highest level. Aimag governors, for example, are appointed by the prime minister.

There is an inherent tension in the PSMFL in seeking to increase publicsector effectiveness in delivering high-quality services to such a dispersed population while also exercising fiscal restraint. One legacy of the former socialist regime, which achieved remarkable (though fiscally unsustainable) health and education outcomes, was a high political expectation that these public services would continue to be delivered at similar levels in the future. This is one half of the twin paradox that the PSMFL struggles to resolve: how to deliver more with less.

Powerful governors at aimag and sum level are the key actors in local space, but in practice they have little downward accountability to their local constituencies. The primary accountability of governors is upwards to central government. While aimag- and sum-level assemblies (khurals) are elected, their actual role as oversight bodies is very limited. Their functional jurisdiction is vaguely defined and they appear to be more a forum for consultation than for making decisions. This is unlike the state Great 
Khural (national parliament), which is empowered to initiate or amend legislation and has a constitutionally defined role in which it must approve and legislate on certain decisions before the executive branch of government can act.

Mongolia has made significant strides since 1990 towards creating a decentralised democracy, including this important separation of citizens' representative assemblies from the executive branches of government which, at least in theory, they oversee. At the sub-national level, however, the system of inter-governmental transfers currently in place has not created fiscally autonomous, self-governing local authorities for three main reasons [World Bank, 2002]. First, there are large asymmetries between the expenditure responsibilities of local governments (which have been growing) and their decision-making authority (which is heavily circumscribed by the many mandated functions they are assigned in law, notably in service delivery). Second, local governments have little or no capacity to raise revenues of their own. Third, the system of intergovernmental transfers on which sub-national governments rely for the overwhelming majority of their revenues is unpredictable and inequitable. Overall, levels of fiscal decentralisation are very modest indeed.

The financial autonomy of sub-national governments is currently restricted under the budgetary process and the General Taxation Law (2000), which subjects all major taxes to state legislation - including payment for use of 'state resources' such as mineral deposits, land, timber and water. Sub-national governments have the right to levy user fees for certain natural resources (for example, natural plants other than timber, and mineral springs), but these revenue sources are very small in relation to local budgetary needs - which leads to extreme fiscal dependence on central government. The revenue and expenditure autonomy of sums and bags is negligible, and accounts for less than one per cent of all budget revenues and expenditures in Mongolia. Local khurals can levy taxes on local enterprises, but in practice virtually all enterprises are registered in Ulaanbaatar and a few other urban centres. Intergovernmental transfers are also subject to political bargaining. Horizontal inequities between sub-national jurisdictions are striking, but do not necessarily correspond to the widely varying size of the populations and tax bases.

The other half of the twin paradox facing the PSMFL, then, is how to achieve downward accountability of public sector institutions to their local constituents when the financial resources on which they depend are derived almost entirely from the centre. This creates an inbuilt tendency for upward accountability to predominate. Local people are more likely to demand accountability from public institutions - and local governments are more likely to be responsive - when local resource mobilisation and/or transparency in inter-governmental transfers are more closely matched with public servicedelivery obligations. This remains a distant goal in Mongolia. 
In summary, a highly imbalanced pattern of decentralisation prevails in Mongolia compared with a sample of 14 other developing countries (see Figure 1). This snapshot captures the intended and unintended consequences of past policies as actually implemented, whether or not those policies were promulgated in the name of decentralisation. Measured against a set of standardised criteria developed by the World Bank for this purpose, contemporary Mongolia has been characterised by substantial though incomplete political decentralisation, but little administrative decentralisation and virtually no fiscal decentralisation [McLean, 2001]. ${ }^{8}$ Administrative decentralisation follows a deconcentrated pattern in which governors and their staffs report upwards to the next-highest level of government, while technical staff report primarily to national line ministries or their respective provincial departments. There is little opportunity for elected assemblies to exert any influence over technical department staff and quality of service delivery at their respective level of government, and therefore little incentive for local populations to use their elected representatives as a channel for articulating concerns and making claims in this respect. Evidence from the Mongolia Participatory Living Standards Assessment 2000 confirms that community members are widely dissatisfied with the extent to which local governors and elected representatives take account of their needs and aspirations [NSO and World Bank, 2001].

FIGURE 1

NATIONAL DECENTRALISATION BY DIMENSION IN MONGOLIA AND 14 OTHER COUNTRIES

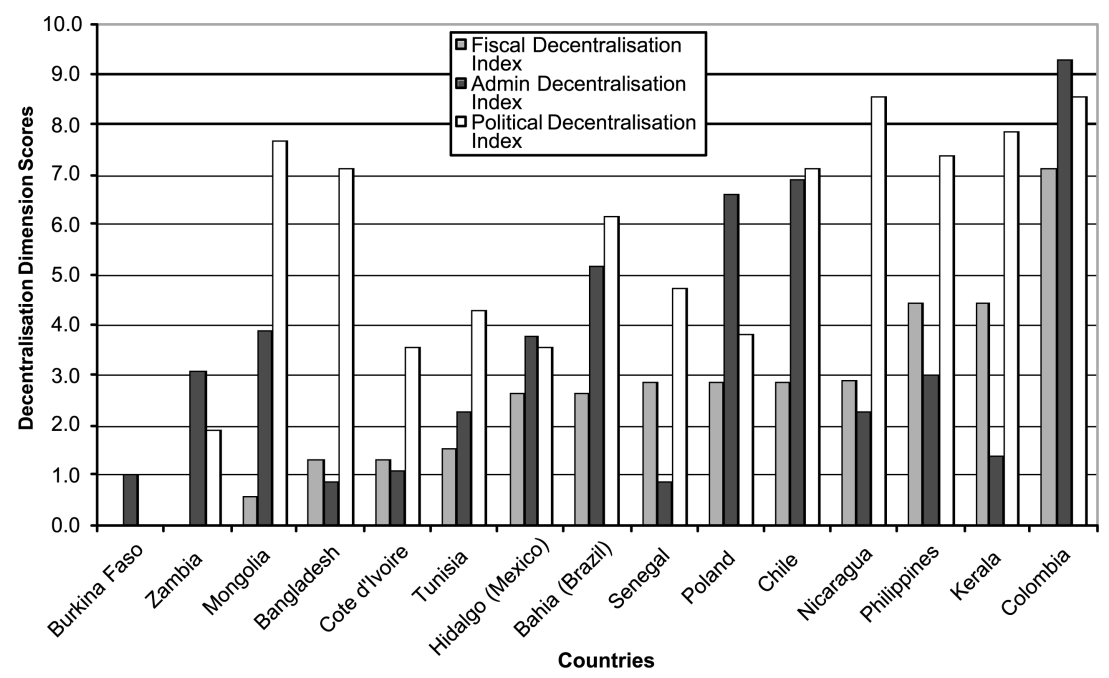


IV. DECENTRALISATION AND PASTURE-LAND MANAGEMENT: AN UNFINISHED AGENDA

Against this challenging background within which decentralisation reforms are being pursued, we now examine the forms decentralisation has taken in the specific case of pasture-land management. Under Mongolian conditions, sustainable pasture-land management is primarily achieved by maintaining a spatial separation between the pastures used in different seasons and ensuring that they are grazed only in those seasons ('time-partitioning'). Local patterns of resource use can vary widely from year to year given natural variability in precipitation and forage growth [Mearns, 1993b]. Spatial and social (usergroup) boundaries therefore tend to be deliberately 'fuzzy', permeable, overlapping and dynamic, which calls for resilient institutional forms to enable groups of resource users to co-ordinate their actions, make internal agreements 'stick' with credible sanctions, and renegotiate access rights on an ongoing basis [Bruce and Mearns, 2002; Fernández-Giménez, 2002; Goodhue and McCarthy, 2000; Turner, 1999]. For such local-level collective action to be effective, various forms of support are required from the state, particularly in making essential infrastructure investments and providing inputs and services to help manage risk, in the transparent and fair adjudication of disputes when local mechanisms fail, and in providing for negotiation between higher-level authorities over resource-access rights during times of drought or winter emergency.

Institutional arrangements governing pasture-land management have undergone profound transformation over the past decade in ways that reflect a virtual abdication of public administration rather than decentralisation or purposive intervention. This is in contrast to earlier periods in modern Mongolian history - most notably during collectivisation in the 1950s to 1980s - in which apparently radical changes at the formal level took rather syncretic, adaptive forms in practice [Mearns, 1993b; Fernández-Giménez, 1999]. Such adaptive outcomes in the post-transition era may yet emerge. For the time being, however, pasture-land use is characterised more by a breakdown in established co-ordination norms. This is owing to a dramatic rise in the number and heterogeneity of herders combined with the near absence of public support in areas critical to the security and sustainability of their livelihoods.

Significant changes in pasture-land management practice were introduced under collectivisation, including investments in water supply, winter shelters, hay and fodder production, and transportation for making nomadic moves, and species-specialisation in livestock production at the herder camp level [Humphrey, 1978]. While some of these changes partially displaced customary forms of collective action in herding, and tended to restrict seasonal nomadic moves within bag (then known as 'brigade') territories, they did not alter 
the basic seasonal rhythm of pasture-land use. In many respects, pasture-land management under collectivisation was marked by the dual control of formal regulatory institutions and informal co-ordination norms [Mearns, 1993a, $b$; Fernández-Giménez, 1999]. Nominal control of decisions concerning who would graze where and when was transferred from individual households to managers of pastoral collectives and state farms, but in practice the outcomes varied little from customary tenure patterns.

During the 1990s, with the onset of economic transition, several important shifts in pasture-land management practice were brought about. One of the most striking features of change in rural Mongolia in the early 1990s was the re-emergence of the khot ail as the primary unit of social organisation among herders in all but the most arid regions of Mongolia [Mearns 1993b, 1996]. ${ }^{9}$ The khot ail is a fluid group of herding households that co-operates in livestock and pasture management, notably to take advantage of labour economies of scale. It appeared in the early 1990s that khot ails might have the potential to 'federate' upwards spontaneously into informal grazing associations and to perform an important function in regulating access to seasonal pastures, mimicking the formal process of 'time-partitioning' of pasture use that prevailed under the collectives. This potential was generally not realised, however, as a result of other driving forces that limited the extent to which herding communities could operate as self-governing grazing associations. ${ }^{10}$

For example, limited livelihood opportunities outside the livestock sector during the harsh economic conditions of the early-to-mid-1990s led to a doubling in the number of herding households, which increased as a share of total population from 17 per cent in 1990 to around 35 per cent by the mid1990s. ${ }^{11}$ As rural communities swelled in size, they also became more heterogeneous. The gains from the privatisation of state and collective assets were unequally distributed, and inequality in livestock holdings began to increase dramatically. Older, more established and new herding households had divergent interests and levels of skill and experience in livestock production, which both contributed to rising inequality and reduced the likelihood of successful collective action in pasture-land management [Mearns, 1996].

Newer herding households tended to be formerly non-herding state employees made redundant by economic liberalisation, and were more likely to remain sedentary for much of the year in locations close to settlements where access to markets and social services was more assured. In many places they were often marginalised in the distribution of winter shelters, which rendered them more vulnerable to livestock mortality during harsh winter conditions, and more dependent on social connections with established herders with more secure claims over winter camp sites and associated pastures as a means of gaining access to pasture. The net effect of changes of this sort was 
a marked decline in pastoral mobility and an over-concentration of grazing pressure around settlements and close to roads. As argued below, this decline in mobility has emerged as one of the principal threats to the sustainability of pastoral livestock production [WRI, 2000; World Bank, 2003; see also NiamirFuller, 1999]. ${ }^{12}$

While these changes may not give the appearance of decentralisation, a decentralisation of sorts has taken place as the state has retreated from a direct role in regulating pasture-land allocation and use. In the institutional vacuum that has prevailed, the rules or claims that take precedence in determining who grazes where and when are often unclear. The land law enacted in 1994 appeared to provide a permissive or enabling framework for sustainable pasture-land management, but it contained significant areas of ambiguity - and key actors received little guidance as to how to interpret and apply the law in practice. As a result, divergent approaches to adjudicating claims and resolving the now widespread pasture-land disputes have been adopted in different jurisdictions [Erdenebaatar and Batjargal, 2001; Fernández-Giménez and Batbuyan, 2000; Hanstad and Duncan, 2001; Mearns, 1997].

One such source of ambiguity concerned the definition of the term 'common land'. While pasture land is constitutionally protected from privatisation, the ability of herding communities to use the 1994 land law to underwrite controlled-access commons was compromised by a deeply rooted ethic of open access among Mongolian herders. This prevented herder communities from legally denying 'outsiders' or non-members of their communities from gaining access to local pasture, or from insisting that such access be granted only following explicit negotiation. By the late 1990s, many observers had come to the conclusion that controlled-access pastoral commons in Mongolia - while judged to be necessary for the sustainability of pastoral livelihoods and land management - would be unworkable in the absence of flexible guidelines to aid in implementing the relevant provisions of the land law. Such guidelines would, for example, allow self-governing herder groups to hold joint possession of pasture land for use during each season, regulate the time-partitioning of pasture use and exclude non-members - subject to negotiated and reciprocal rights of access to other groups during declared times of drought or winter stress.

\section{ACTORS IN DECENTRALISATION OF PASTURE-LAND MANAGEMENT}

At the central level, the key actors in pasture-land management are the Ministry of Nature and Environment (MNE) and the Ministry of Food and Agriculture (MFA), but significant tensions exist between these bodies. Briefly stated, the role of MFA has been in decline throughout the 1990s while MNE 
has been in the ascendancy - at least as far as control over land management is concerned. MFA, with authority over all state farms, and its counterpart for pastoral collectives the Supreme Council of Collectives, enjoyed considerable power throughout the state-socialist era, and were jointly responsible for all policies and planning decisions regarding agricultural land use. Responsibility for land management was transferred to MNE in the early 1990s and, under the growing influence of Western notions of environmental management, a series of environmental laws was enacted, including the 1994 land law (effective in 1995) which was regarded as a tool for conservation-oriented rather than production-oriented land management. MFA's role in land management disappeared in the early 1990s, along with any budget for land affairs ironically, since this coincided with the period in which herders greatly increased in number and as a share of total population - but this loss of influence remains contested within the MFA and its constituent agencies. Some actors within and associated with MFA, for example, have attempted to draft a law specific to pasture-land tenure, although their efforts have been poorly co-ordinated with other initiatives related to the further development of land legislation.

For present purposes, the principal actor with respect to pasture-land management rests at sum (rural district) level, in the person of the sum governor. The aimag (provincial) administration is much less involved in pasture-land management, except (in principle) in setting aside land for use as inter-sum grazing reserves during times of drought or $d z u d$ hazard. ${ }^{13}$ During the collective era, the sum governor was also the director of the eponymous collective (negdel), and the territorial boundaries of the sum and the negdel, at least by the end of the 1980s, were coterminous. Known as the sum darga (boss), he enjoyed considerable discretionary power within his jurisdiction, while being upwardly accountable only to superiors at higher levels in the highly centralised state structure. Following decollectivisation around 1991-92, and the privatisation of the assets of the collective, many sum dargas were retained as the managers of the companies and co-operatives that typically acquired the lumpy assets (equipment, buildings, inventory) of the former collectives, and there was often significant continuity in management style and content. Even the upward accountability was retained, as the now ostensibly private companies and co-operatives maintained their federal structure at the national level through membership in the National Association of Mongolian Agricultural Co-operators (the successor to the Supreme Council of Collectives). Land management practice in many of these sums continued for a time much as it did during the collective era, albeit driven to generate profits through trading rather than to meet the production quotas of central planning. Other sum dargas were quickly appointed as the new sum governors. 
In practice, sum governors currently have considerable discretion to interpret and enforce the land law as they see fit, an activity not generally constrained by their lack of financial resources. This leads to considerable local variation in resolving claims to winter camp sites, often regarded as the key to obtaining secure access to winter pasture (which, in turn, is an important determinant of success in pursuing a pastoral livelihood strategy). For example, in one sum, the governor may declare that in privatising the winter shelters created under the collective (negdel), preference would be given to those herders who were most frequently allocated those shelters during the collective era. In another, perhaps even adjoining sum, the governor may declare that preference would be given to the claims of those who could claim some birthright to the site, perhaps by virtue of their own or their father's residence there prior to the establishment of the collective. Little or no guidance is offered or available to sum governors from the centre in resolving such competing claims, and in areas where winter shelters and camp sites are in high demand and short supply (depending on local ecological and topographic conditions and rates of in-migration following decollectivisation) this can be a serious and continuing source of land dispute [Mearns, 1997; Erdenebaatar and Batjargal, 2001].

\section{THE NATURE OF POWERS DEVOLVED}

For pasture-land management, the key powers in question that are transferred from central to sub-national levels concern the setting of rules to govern the allocation of camp sites and associated sets of pastures among local herders, compliance with those rules and the adjudication of disputes. The principal mechanism for the transfer of these powers is the land law [GoM, 2002b]. At the same time, central government has transferred to local governments primary responsibility for drought- and $d z u d$-preparedness, but without the budgetary resources needed to ensure that this responsibility will be met adequately.

Chronic under-provisioning of local efforts to support pastoral risk management (for example, through hay and fodder preparation and distribution) throughout most of the decade of the 1990s led to massive livestock mortality in the three consecutive $d z u d$ years of $1999 / 2000$ to $2001 / 2002$, amounting to a total loss of around one-fifth of the national herd. In early 2001, the government passed Resolution 47 calling for measures to ensure better drought- and $d z u d$-preparedness, and specified the roles of each tier of public administration in establishing an effective and co-ordinated national system for pastoral risk management. At the time of writing it remains unclear whether the resources required to implement such a strategy will be provided for in the medium-term framework for national budgeting. 
Under the land law, a deconcentrated arrangement of powers and responsibilities is envisaged whereby land disputes arising at any one level of administration are to be passed up to the next higher level for administrative resolution. No clear role is defined for other actors such as civil courts. Considerable ambiguity also exists in practice in specifying the distinct roles of different levels of administration. Sum governors appear to believe they have little scope for discretionary decision-making, while in practice they are seen to exercise considerable residual power in the absence of clear guidelines for the interpretation and implementation of the law [Fernández-Giménez and Batbuyan, 2000].

A new land law was enacted in June 2002 [GoM, 2002b], and came into effect on 1 May 2003. The primary motivation for revising the 1994 land law was to make possible, for the first time and in a limited way, a land market in Mongolia. That is, long-term possession licences over certain types of land may now be transferred by sale/auction and may be mortgaged, in addition to transfer by inheritance as was provided for in the 1994 law. The types of land in question are urban and peri-urban land, household plots in general (including land under herders' winter camps), vegetable gardens, hayfields and arable land, amounting to a total of around two per cent of Mongolia's land area.

The basic provision of the 1992 Constitution and 1994 land law with respect to pasture land (representing 80 per cent of all land) remains unchanged: namely, that pasture land shall be the property of the state and protected from private ownership. However, the new land law also 'clarifies' some of the ambiguity inherent in the 1994 law in such a way as to bring out the sharp internal contradiction between wishing to maintain free access to pastures for all as 'common tenure' [sic] land and wishing to ensure that timepartitioning in pasture use is closely observed at the bag level and below [GoM, 2002b: Art.54]. That is, "pasturelands, water points in pasturelands, wells and salt licks' are among those types of land that, 'regardless of whether they are given into possession or use, shall be used for common purpose under government regulation' [GoM, 2002b: Art.6.2]. Furthermore, the law specifically provides for the unhindered right of entry or passage for any person in the case of land that is unfenced or not marked by warning signs, regardless of its tenure status [GoM, 2002b: Art.48]..$^{14}$ It also, however, insists that 'winter and spring pastures shall be prevented from livestock grazing during summer and autumn' [GoM, 2002b: Art.54] and provides for sanctions (fines plus compensation) to be imposed in cases of out-of-season trespass [GoM, 2002b: Art.66].

In early 2001 the MNE at central government level opened up an important channel for downward accountability by agreeing with a civil society lobbying coalition to host a national-level public forum for discussion on the content of 
the then draft land law. It is not clear why MNE acted in the way that it did, other than being persuaded by leading champions within the coalition of lobbyists. Whatever the origins of the initiative, however, a discussion draft of the revised law was released, comments were invited from the public via print media, a national-level public workshop was held and a televised debate took place, collectively representing an unprecedented step in Mongolian legal history. Not all of the demands of this lobbying group were reflected in the final version of the law, but there is little doubt that the fact this process took place at all represents a significant step forward in promoting downward accountability in legislative development. Many observers, however, would now argue that the major obstacle to transparent and accountable governance of land management, including pasture-land management, lies in implementation rather than in the promulgation of new legislation [Hanstad and Duncan, 2001].

\section{SOCIAL DIFFERENCE, ADMINISTRATIVE ACCOUNTABILITY AND REPRESENTATION}

In this section, we consider the nature of accountability relationships between herders and local administrators, and show how social networks among them position elite herders to capture a disproportionate share of the benefits in pasture-land access and control - thereby excluding poorer, more vulnerable herders. Herders themselves, recognising the ambiguity that exists in public administration with respect to pasture-land management, are increasingly likely to take matters into their own hands and to act unilaterally in pastureland use decisions. The increasing heterogeneity of herding communities also makes individual as opposed to collective action more likely. Different types of herders have developed complex strategies to exploit the opportunities open to them, depending on their distinct social and economic positions.

Wealthier herders, with large herds and, typically, better endowments of adult family labour, are likely to employ strategies of family-splitting to ensure that they can guard their valued winter camp sites and associated pastures against out-of-season trespass by others. At least one family member may remain resident all year round at the winter camp, and a permanent wooden structure may be constructed in some areas to reinforce the visibility of the claim being exercised. In such cases, winter shelters and the land on which they stand (though not the pasture land surrounding them) are now commonly privately owned, with documented evidence of possession rights. Serious conflicts may still emerge if competing claims to the surrounding pastures are made by two herders with equally large herds. Herders with small herds will usually be tolerated even if they camp close to the winter pastures claimed by a wealthy herder, since a certain level of 'free riding' is unlikely to undermine the prospects for sustainable pasture-land use [Mearns, 1996]. 
Poorer herders, who are often those with lower levels of skill and experience in herding, and often with large families including the small children of other dependents, have tended to become increasingly reliant on wealthier kin for survival where they continue to pursue livestock-based livelihoods. A form of labour market has emerged, albeit involving in-kind rather than market-based transactions, in which poorer herders will work as labourers for wealthier herders in arduous tasks, such as clearing out winter shelters, herding, or looking for lost animals, in return for the right to join the $k$ hot ail of the wealthier herder and thereby gain more secure access to grazing for the few animals they own. Those poorer, 'new' herding households without such resources of 'social capital' to draw on often failed at herding within a short space of time, and having 'eaten away' the assets of animals they received at the time of privatisation in the early 1990s they returned to live in sum or aimag centres - usually dependent on limited social welfare payments [NSO and World Bank, 2001].

In this context of divergent livelihood strategies among herders within the same rural communities, the downward accountability of local governors in matters of pasture-land dispute resolution is far from symmetrical and transparent. Wealthier, elite herders frequently enjoy better relations with local governors, and are both able and willing to invest considerable resources in hospitality when the darga visits in order to keep open informal channels of communication to encourage the governor to 'turn a blind eye' or to resolve disputes in their favour. Such opportunities to exercise informal influence are not generally available to poorer, more marginal herders, particularly if they have migrated into the area in question from another aimag. Inter-regional migrations of this sort became a recognised livelihood strategy in the later 1990 s as those able to do so would move to take advantage of the better household-level terms of trade in more central, market-accessible parts of the country [NSO and World Bank, 2001].

In the institutional vacuum created by incomplete decentralisation, a 'tragedy of open access' has therefore emerged - with socially differentiated results. Against such a background, some local civil society groups have sought to explore whether opportunities can be exploited to enhance the downward accountability of more receptive sum governments in pasture-land management, and recreate 'meso'-level institutional mechanisms to co-ordinate individual herders' actions in pasture-land use and management so as to facilitate more sustainable and socially inclusive outcomes. Some of these groups are beginning to facilitate pilot projects, with donor support, to fieldtest approaches to group-based pasture-land tenure and management. In some cases, with the moral backing of local administrations, they have been able to go beyond the limits proscribed in the land law to confer possession contracts on groups of around ten to 20 herding households over all sets of pastures 
customarily used by those groups. Many questions remain to be resolved concerning the representativeness and legitimacy of such groups among other, non-group members in the same districts; the concurrence or otherwise of social group and territorial/resource-unit boundaries; the degree to which such initiatives remain dependent on donor financing; and the operational rules for negotiating reciprocal rights of access to non-group members during times of drought or dzud. However, these pilot projects should be recognised as advancing a positive reform agenda that seeks to achieve more environmentally sustainable and socially inclusive outcomes in pasture-land management through efforts to increase the transparency and downward accountability of local governors' offices, elected representatives and sumlevel technical staff.

\section{CONCLUSION: TOWARDS A MORE COMPLETE DEMOCRATIC DECENTRALISATION OF NATURAL RESOURCE GOVERNANCE}

This contribution has argued that incomplete or 'empty' decentralisation with respect to pasture-land management in post-socialist Mongolia has had adverse consequences for pastoral livelihoods and for the environment. This concluding section first summarises some of the issues raised by this case study and ends by identifying some of the missing elements of a democratic decentralisation agenda that would help to restore environmental and social justice.

In the absence of alternative livelihood opportunities following postsocialist transition, the 1990s saw a dramatic reassertion of the importance of pastoral livelihoods in Mongolia. The number of herding households more than doubled, and herders once again comprise around a third of the national population. While Mongolia may offer valuable lessons to other countries in which pastoralists form a significant share of the population, this trend should not be regarded as an entirely positive one. Economic 'transition' is something of a misnomer; indeed, in relation to natural resource governance, the notion of an institutional vacuum is more fitting. Both rural and urban livelihoods throughout the 1990s were marked by rising vulnerability - pastoral livelihoods in particular became increasingly vulnerable in the face of natural hazards - in the absence of supporting reforms that would match devolution of responsibilities to sub-national governments with the budgetary resources to carry them out, and accountability reforms that would subject the actions of local governments to public scrutiny from their constituents.

Many other changes took place in rural livelihood strategies and dynamics. Distinct patterns of inter-regional and rural-urban migration emerged in response to changing livelihood and market-access opportunities, according to which very different opportunities arose for better-off herders than for poorer 
herders and other marginal groups in rural society. These patterns have had profound consequences for the distribution of grazing pressure, resulting in an observably adverse impact on the pastoral environment - notably in shrub vegetation communities in the Gobi-steppe transition zone. At the same time, large areas of good grazing remain under-utilised in more remote areas for want of investments in water supply, social service provision and transportation infrastructure, which in turn are severely constrained by the fiscal crisis facing local governments.

The 1990s has also seen a breakdown of the long-standing forms of dual formal/informal regulation of pasture-land management that had persisted throughout the era of agricultural collectivisation. Some of the principal sources of pressure also relate to changing livelihood dynamics, including: rising levels of asset inequality (notably in livestock holdings) combined with limited options for livelihood diversification; population concentration around settlements, roads/markets and points of social service provision; and emergent labour markets in rural areas, which - among other coping and adaptive strategies - have had important consequences for social capital. The rising vulnerability of more marginal groups has resulted from various combinations of declining asset holdings and adverse household terms of trade, and reduced access to common-pool grazing and benefits from increasingly exclusionary forms of social capital.

To what extent are these outcomes attributable to the 'decentralisation' attributes of economic and political transition itself, and to what extent to the consequences of this transition for livelihood opportunities more broadly? While the causal relationships among these factors are attenuated and difficult to disentangle, it is suggested that democratic decentralisation of natural resource governance has had at least some influence on the outcomes under discussion, although it has not yet gone far enough. To date, its scope has been limited to attempts rigidly to prescribe rules of tenure and administrative authority through the introduction of new legislation, rather than to seek clarity and transparency in rules-setting mechanisms to address necessarily 'fuzzy' pastoral-resource access rights. Moreover, the backdrop of institutional flux and uncertainty that characterises all post-socialist transitions has not so far been conducive to fostering the predictability in expectations among social actors that democratic decentralisation reforms demand.

Limited space prevents a full discussion of possible avenues for future research and policy analysis, but some of the missing elements of this unfinished democratic decentralisation agenda include: 1) promoting public access to information on land legislation and the relevant actions and responsibilities of local governments; 2) continuing support for ongoing institutional innovations to increase the downward accountability of local governments in pasture-land management; 3) developing alternative 
approaches to pasture-land dispute resolution to complement the administrative options enshrined in the land law; 4) fostering public consultation in the further development of national land legislation; and 5) most importantly, elaborating flexible, context-sensitive implementation guidelines and manuals for use by local governors and their staff in upholding the land law in transparent and accountable ways.

\section{NOTES}

1. The problem of attribution of environmental outcomes to changes in public policy is not unique to decentralisation or post-socialist transition. A growing literature on the imputed environmental implications of 'structural adjustment' suffers from similar methodological flaws, as discussed elsewhere [Mearns, 1991]. Other analytical frameworks that offer insights into the linkages between public policies and livelihood and environmental outcomes include the environmental entitlements framework [Leach et al., 1999], the capitals and capabilities framework [Bebbington, 1999] and the sustainable livelihoods framework [e.g., Ellis, 2000].

2. This has been defined as 'The right to a safe, healthy, productive and sustainable environment for all', irrespective of individual and group identities - including socio-economic status (Environmental Justice Resource Center at Clark Atlanta University, http://www.ejrc.cau.edu/). In this essay the term is used broadly to refer to equitable access to pasture land and associated key resources, such as water sources and salt licks.

3. The Participatory Living Standards Assessment 2000 [NSO and World Bank, 2001], led by the author, drew on the experiences and perceptions of some 2,000 rural and urban community members throughout Mongolia, systematically elicited using participatory learning and action methods, in order to compile a profile of livelihood sources, strategies and dynamics throughout the 1990s. These were differentiated according to well-being status, gender, age and geographical (regional and rural/urban) location.

4. See Law of Mongolia on Regionalized Development Management and Coordination [GoM $2003 a$ ] with supporting documents, including the Regional Development Concept (approved by parliament in 2001) and Medium-Term Regional Development Strategy.

5. Anecdotal evidence suggests that the official data from the National Statistical Office of Mongolia underestimate the population of Ulaanbaatar, owing to high rates of influx of unregistered in-migrants in recent years. Some estimates put the true population of Ulaanbaatar at closer to 1 million.

6. An exception to this is the bag, in which the khural comprises all residents who have reached the age of majority. The bag is not formally a territorial or budget entity.

7. The Decentralisation Assessment Module was developed by Hans Binswanger, Andrew Parker, Johan van Zyl, Suzanne Piriou-Sall, Keith McLean, Graham Kerr and Melissa Williams as a product of the 'Decentralisation, Fiscal Systems and Rural Development' research project. Analytical framing for this research was provided by Manor [1999].

8. It is important to note that the definitions of these terms as used by McLean [2001] differ significantly from those used by Ribot [2002]. To assist in making cross-country comparisons, the Decentralisation Assessment Module used by McLean [2001] employs a set of indicators to characterise the three dimensions of decentralisation: administrative, fiscal and political. 'Administrative decentralisation' refers primarily to accountability relationships between civil servants and local governments. 'Political decentralisation' refers to the extent and transparency of an electoral system at various levels of government, and the degree to which election outcomes are representative. 'Fiscal decentralisation' refers to the degree of local government autonomy over revenue-raising capacity and expenditure decisions. For Ribot, 'political or democratic decentralisation occurs when powers and resources are transferred to authorities representative of and downwardly accountable to local populations' [Ribot, 2002: 4], while fiscal decentralisation is considered to be a cross-cutting element of both deconcentration 
(or administrative decentralisation, again contra the definition used by McLean [2001]) and political decentralisation.

9. Khot ails based on kinship ties were suppressed during the collective era of the 1950s-1980s, being temporarily replaced by ostensibly non-kin-based production units of one or two households - known as suuri.

10. For further views on the character and historical dynamics of the khot ail as an institution, see Bold [1996] and Sneath [1999].

11. It is important to note that the National Statistical Office of Mongolia distinguishes between fulltime 'herding households' (which rely primarily on livestock as a source of livelihood) and 'livestock-owning households' (for which livestock is not the primary source of livelihood), and reports data for both categories. While the number of full-time herding households increased steadily through the 1990s, the total number of livestock-owning households actually declined slightly over the same period, after an initial increase during 1990-92. This initial increase was largely accounted for by household-splitting to form new households so that extended families could maximise their entitlements to livestock from the privatisation of state and collective assets - which were calculated on a per-household basis.

12. In spite of the recent relative decline in pastoral mobility in Mongolia, levels of mobility remain significantly higher than in the neighbouring Inner Mongolia Autonomous Region (IMAR) of China. A graphic illustration of the environmental consequences of this difference in livestockproduction strategies is seen in satellite imagery of Mongolia's southern border with China, from which the generally poorer vegetation condition of IMAR compared with Mongolia can be clearly discerned [Sneath, 1998]. This simple illustration is a clear demonstration of the importance of pastoral mobility for sustainable grassland management in dryland Inner Asia.

13. Dzud is the Mongolian term for a range of winter weather conditions that make forage from natural pastures inaccessible to domestic grazing animals.

14. This currently includes all pasture land. Herders tend to be bitterly opposed to any moves towards fencing pasture land [Hanstad and Duncan, 2001; Fernández-Giménez and Batbuyan, 2000].

\section{REFERENCES}

Agrawal, A. and J. Ribot, 1999, 'Accountability in Decentralization: A Framework with South Asian and West African Cases', Journal of Developing Areas, Vol.33, pp.473-502.

Bebbington, A., 1999, 'Capitals and Capabilities: A Framework for Analyzing Peasant Viability, Rural Livelihoods and Poverty', World Development, Vol.27, No.12, pp.2021-44.

Bold, B-O., 1996, 'Socio-Economic Segmentation: Khot-ail in Nomadic Livestock Keeping of Mongolia', Nomadic Peoples, No.39, pp.69-86.

Bruce, J.W., and R. Mearns, 2002, 'Natural Resource Management and Land Policy in Developing Countries: Lessons Learned and New Challenges for the World Bank', Drylands Programme Issues Paper No.115, London: International Institute for Environment and Development.

CPR, 2002, Rural Development Strategy for Mongolia, Draft report to Government of Mongolia, Ulaanbaatar: Center for Policy Research.

Ellis, F., 2000, Rural Livelihoods and Diversity in Developing Countries, Oxford: Oxford University Press.

Erdenebaatar, B. and N. Batjargal, 2001, Pasture Land Disputes and Conflict Resolution: Cases from Mongolia, Ulaanbaatar: Asia Foundation.

Fernández-Giménez, M.E., 2002, 'Spatial and Social Boundaries and the Paradox of Pastoral Land Tenure: A Case Study from Post-Socialist Mongolia', Human Ecology, Vol.30, No.1, pp.49-78.

Fernández-Giménez, M.E., 1999, 'Sustaining the Steppes: A Geographical History of Pastoral Land Use in Mongolia', Geographical Review, Vol.89, No.3, pp.315-42.

Fernández-Giménez, M.E. and B. Batbuyan, 2000, 'Law and Disorder in Mongolia: Local Implementation of Mongolia's Land Law', Paper presented at Eighth Biennial Conference of the International Association for the Study of Common Property, Bloomington, IN 31 May-4 June.

GoM, 2003a, Law on Regionalized Development Management and Coordination, Ulaanbaatar: Government of Mongolia. 
GoM, 2003b, Economic Growth Support and Poverty Reduction Strategy, Ulaanbaatar: Government of Mongolia.

GoM, 2002a, Public Sector Management and Finance Law, Ulaanbaatar: Government of Mongolia. GoM, 2002b, Land Law of Mongolia, Ulaanbaatar: Government of Mongolia.

GoM, 2001, The Government of Mongolia Good Governance for Human Security Programme: Policy Document, Ulaanbaatar: Government of Mongolia.

GoM, 2000a, Action Programme of the Government of Mongolia, Ulaanbaatar: Government of Mongolia.

GoM, 2000b, 'National Environmental Action Plan 2000' (final draft dated 9 June 2000), Ulaanbaatar: Government of Mongolia.

Goodhue, R.E. and N. McCarthy, 2000, 'Fuzzy Access: Modeling Grazing Rights in Sub-Saharan Africa', in N. McCarthy, B. Swallow, M. Kirk and P. Hazell (eds.), Property Rights, Risk, and Livestock Development in Africa, Washington, DC and Nairobi: International Food Policy Research Institute and International Livestock Research Institute, pp.191-210.

Hanstad, T. and J. Duncan, 2001, 'Land Reform in Mongolia: Observations and Recommendations', RDI Reports in Foreign Aid and Development, No.109, Seattle: Rural Development Institute for the World Bank.

Humphrey, C., 1978, 'Pastoral Nomadism in Mongolia: The Role of Herdsmen's Cooperatives in the National Economy', Development and Change, Vol.9, No.1, pp.133-60.

Leach, M., R. Mearns and I. Scoones, 1999, 'Environmental Entitlements: Dynamics and Institutions in Community-based Natural Resource Management', World Development, Vol.27, No.2, pp. $225-47$.

Manor, J., 1999, The Political Economy of Democratic Decentralization, Directions in Development Series, Washington, DC: World Bank.

McLean, K., 2001, 'An Assessment of Decentralization in Mongolia', Washington, DC: World Bank, mimeo.

Mearns, R., 1997, 'Pasture-land Use and Social Dynamics' and 'Legislative and Institutional Framework for Pasture-land Management' in 'Study of Mongolian Extensive Livestock Production Systems', Final Report to Asian Development Bank under TA No.2602-MON, Calgary: Agriteam Canada Consulting.

Mearns, R., 1996, 'Community, Collective Action and Common Grazing: The Case of Post-Socialist Mongolia', Journal of Development Studies, Vol.32, No.3, pp.297-339.

Mearns, R., 1993a, 'Pastoral Institutions, Land Tenure and Land Policy Reform in Post-Socialist Mongolia', PALD Research Report No.3, Brighton: Institute of Development Studies, University of Sussex.

Mearns, R., 1993b, 'Territoriality and Land Tenure among Mongolian Pastoralists: Variation, Continuity and Change', Nomadic Peoples, Vol.33, pp.73-103.

Mearns, R., 1991, 'Environmental Implications of Structural Adjustment: Reflections on Scientific Method', IDS Discussion Paper No.284, Brighton: Institute of Development Studies, University of Sussex.

NCSDM, 1999, Mongolian Action Programme for the 21st Century (MAP21), Ulaanbaatar: National Council for Sustainable Development of Mongolia.

Nelson, J., C. Tilly and L. Walker (eds.), 1997, Transforming Post-Communist Political Economies, Washington, DC: National Research Council, Task Force on Economies in Transition.

Niamir-Fuller, M. (ed.), 1999, Managing Mobility in African Rangelands: The Legitimization of Transhumance, London: Intermediate Technology.

NSO, 2001, 2000 Population and Housing Census: The Main Results, Ulaanbaatar: Mongolian National Statistical Office.

NSO and World Bank, 2001, Mongolia Participatory Living Standards Assessment 2000, Ulaanbaatar: Mongolian National Statistical Office and World Bank.

Ribot, J.C., 2002, Democratic Decentralization of Natural Resources: Institutionalizing Popular Participation, Washington, DC: World Resources Institute.

Sneath, D., 1999, 'Kinship, Networks and Residence', in C. Humphrey and D. Sneath, The End of Nomadism? Society, State, and the Environment in Inner Asia, Durham, NC: Duke University Press, pp.136-78.

Sneath, D., 1998, 'State Policy and Pasture Degradation in Inner Asia', Science, Vol.281, pp.1147-8. 
Turner, M.D., 1999, 'The Role of Social Networks, Indefinite Boundaries and Political Bargaining in Maintaining the Ecological and Economic Resilience of the Transhumance Systems of Sudano-Sahelian West Africa', in M. Niamir-Fuller (ed.), Managing Mobility in African Rangelands: The Legitimization of Transhumance, London: Intermediate Technology, pp.97-123.

World Bank, 2003, Mongolia Environment Monitor 2003: Land Resources and Their Management, Washington, DC and Ulaanbaatar: World Bank.

World Bank, 2002, Mongolia Public Expenditure and Financial Management Review, Report No.24439-MOG, Washington, DC: World Bank.

WRI, 2000, 'Grassland Ecosystems: Sustaining the Steppe - The Future of Mongolia's Grasslands', in World Resources Report 2000-2001, Washington, DC: World Resources Institute with UNDP, UNEP and World Bank, pp.212-24. 